\title{
NILAI-NILAI KARAKTER PADA BAHASA INDONESIA DAN PENERAPANNYA PADA PROSES PENGEMBANGAN KARAKTER MATEMATIKA DI SEKOLAH DASAR
}

\author{
Jamilah dan Akhmad HB \\ Universitas Terbuka Banjarmasin \\ Jalan Sultan Adam, Banjarmasin, Kalimantan Selatan \\ email: Jamilah-UT@ecampus.ut.ac.id \\ STKIP PGRI Banjarmasin \\ Jalan Sultan Adam Komplek H. Iyus, No. 18 RT. 23 Banjarmasin, \\ Kalimantan Selatan, Kode pos 70121 \\ email: Akhmadhb@stkipbjm.ac.id
}

\begin{abstract}
ABSTRAK
Pengintegrasian pendidikan karakter dengan mata pelajaran yang lain adalah merupakan gagasan yang sangat baik. Hal tersebut mengacu pada perlunya untuk tidak hanya mengajarkan tentang aspek kognitif tetapi juga aspek afektif/nilai dan moral. Dan pengintegrasian tersebut harus dimulai dari sedini mungkin dalam konteks ini adalah Sekolah Dasar. Sebagai pelajaran yang ada disekolah dasar, pendidikan Bahasa Indoneisa memiliki peran yang sangat penting sebagai saran pengajaran karakter secara terintegritas. Bahasa Indonesia yang merupakan bagian dari bangsa Indonesia tentu saja menyinpan aspek-aspek moral yang bisa dijadikan nilai-nilai karakter yang bagus untuk diajarkan kepada siswa. Namun demikian, pengintegrasian pendidikan karakter di proses belajar mengajar Bahasa Indonesia bukan hal yang mudah untuk dikerjakan. Oleh sebab itu, diperlukan pengkajian mendalam baik secara teoritis ataupun praktis untuk mencari cara pengajaran ideal guna tercapainya tujuan pembelajaran tersebut.
\end{abstract}

Kata kunci: nilai, bahasa indonesia, karakter, matematika, sekolah dasar

\section{PENDAHULUAN}

Keberadaan pembentukan karakter sebagai salah satu aspek yang arus dicapai dalam proses pendidikan siswa-siswi semakin mendapatkan tempat dalam setiap proses pendidikan di Indonesia. Hal itu sejalan dengan kuatnya niat dari pemerintah untuk mengintegrasikan aspek pengembangan karakter di setiap proses belajar mengajar pada setiap jenjang level pendidikan di Indonesia. Situasi tersebut diikuti dengan langkah kongkrit pemerintah yang beberapa waktu lalu menerbitkan dan mengaplikasikan kurikulum yang salah satu konsentrasinya adalah untuk membentuk karakter para siswa-siswi. Pemerintah melalui Peraturan Presiden Republik Indonesia No. 87 Tahun 2017 menegaskan bahwa proses penguatan pendidikan karakter dapat dilakukan dengan mengharmonisasi 
beberapa aspek yang salah satu nya adalah olah pikir yang biasa ditemukan dalam konteks sekolah formal. Pada Peraturan Presiden tersebut juga disebutkan bahwa penguatan pendidikan karakter juga harus dilaksanakan pada level sekolah menengah dan sekolah dasar. Dengan demikian pemerintah menginginkan pembentukan karakter dimulai dari proses pendidikan anak di usia sedini mungkin.

Proses pendidikan karakter pada level pendidikan anak usia dini dapat dimulai pada tahapan sekolah dasar .Pada saat berada disekolah dasar, anak didik berada ada usia terbaik untuk menerima pendidikan pembentukan karakter. Dalam bukunya tentang membangun karakter pada usia dini, Prasetyo menejelaskan bahwa masa usia dini adalah masa keemasan bagi anak untuk belajar dan juga akan menentukan sifat-sifat dan karakter anak di masa yang akan datang (Manurung, 2011: 12). Dengan kata lain, memberikan pendidikan yang bisa membentuk karakter siswa sedini mungkin sangat penting untuk dilakukan. Dan pendidikan tersebut bisa dimulai dengan hal yang sangat mendasar yang juga merupakan bagian dari kepribadian siswa tersebut, salah satunya adalah melalui pengajaran Bahasa Indonesia.

Pengintegrasian pendidikan karakter Matematika melalui pengajaran Bahasa Indonesia merupakan langkah tepat ditinjau dari fungsi bahasa. Di tinjau dari fungsi, bahasa bukan hanya sekedar alat untuk mentransfer pengetahuan, tetapi juga sebagai alat transfer nilai dari bahasa tersebut. Dalam tinjauannya (Manurung, 2011: 54) menjelaskan bahwa pembelajara bahasa yang dibarengi dengan penegasan bahwa Bahasa Indonesia adalah bahasa kesatuan bagi seluruh rakyat Indonesia mampu menanamkan nilai moral peserta didik untuk saling menghargai dan menghormati kebargaman budaya yang ada di Indonesia. Sehingga dapat disimpulkan bahwa pembelajaran Bahasa Indonesia efektif sebagai sarana pendidikan karakter bagi siswa sekolah dasar.

\section{Bahasa Indonesia dan Karakter Bangsa Indonesia}

Secara historis, keberadaan Bahasa Indonesia sebagai salah satu wujud dari karakter bangsa Indonesia sendiri telah jauh diakui keberdaannya jauh sebelum bangsa Indonesia mencapai kemerdekaan. Hal tersebut terlihat pada tahun 1928, ketika para pemuda mengikrarkan bahwa Bahasa Indonesia merupakan salah faktor yang merepresentasikan karakter Bangsa Indonesia dengan diakuinya Bahasa Indonesia sebagai Bahasa Nasional. Secara yuridis, kekuatan Bahasa Indonesia sebagai bahasa Bangsa Indonesia ditetapkan dalam UUD 45 pasal 36 yang menyatakan bahwa bahasa Negara adalah Bahasa Indoensia. Dengan kata lain, Bahasa Indonesia merupakan alat pemersatu 
bangsa yang terdapat karakter kesatuan didalamnya. Selain itu, sebagai sebuah produk dari masyarakat Indonesia itu sendiri, Bahasa Indonesia tentunya memiliki unsur-unsur nilai yang merupakan pengejawantahan dari karakter Bangsa Indonesia.

Bukan hanya dari segi historis dan yuridis, hubungan Bahasa Indonesia dengan karakter bangsa Indonesia juga dapat dilihat dari segi fungsi. (Pateda, 2014: 2) dalam artikel nya menjelaskan bahwa fungsi Bahasa Indonesia dalam mengembangkan kepribadian sangatlah besar. Melalui penggunaan Bahasa Indonesia segenap rakyat Indonesia senantiasa terlatih untuk berkepribadian, berprilaku, dan berbudi khas Indonesia. Selain itu menurut Pateda juga menambahkan bahwa penggunaan Bahasa Indonesia yang sesuai dengan tindak tutur dan tata karma akan melahirkan berbudi luhur dan berkarakter. Apabila pembelajaran bahasa dapat secara bersaam merupakan proses pembentukan karakter manusia, maka pengintegrasian pembelajaran Bahasa Indonesia dengan pendidikan karakater di usia dini perkembangan siswa-siswi harus mendapat dukungan penuh dari kalangan praktisi pendidikan.

Bahasa yang merupakan alat komunikasi dikalangan masyarakat adalah produk dari masyarakat itu sendiri. Sehingga dapat dipastikan bahwa dalam bahasa terdapt aspek sosial yang erat kaitannya dengan nilai-nilai karakter. Menurut (Halliday, 1992: 122) bahwa ada tiga hal yang bisa terjadi dalam pembelajaran bahasa, yaitu belajar bahasa, belajar memalui bahasa, dan belajar tentang bahasa. Belajar bahasa adalah proses seseorang belajar suatu bahasa. Proses ini tidak selalu harus diperoleh dengan cara formal, tetapi bisa juga informal. Belajar melalui bahasa adalah proses dimana siswa bisa mempelajari banyak hal melalui bahasa atau dengan kata lain bahasa adalah alat untuk belajar. Yang terakhir adalah belajar tentang bahasa belajar tentang pengetahuan bahasa dan proses ini hanya bisa didapatkan melalui belajar secar formal. Sehingga dapat dikatakn bahwa bahasa bisa menjadi subjek sebuah pembelajaran dan bisa sekaligus menjadi media untuk pembelajaran yang lain. Dengan demikian dapat disimpulkan, bahwa ketika seseorang belajar Bahasa Indonesia maka secara tidak langsung dia tidak hanya belajar pengetahuan Bahasa Indonesia tetapi juga belajar apa yang bisa dipelajari lewat bahasa yang salah satu nya adalah karakter bangsa Indonesai itu sendiri.

\section{Pendidikan Karakter Matematika Melalui Nilai-Nilai Karakter pada Bahasa Indonesia}

Secara umum apa yang disebut dengan pendidikan adalah sebuah proses yang diharapkan bisa membuat siswa berubah menuju yang lebih baik dalam aspek intelektual dan juga moral. Tinjauan 
pendidkikan yang demikian menekankan bahwa pendidikan semestinya hanya tentang bagaimana meningkatkan aspek kognitif siswa, tetapi juga harus menyentuh aspek afektif siswa. Sehingga terjadi kesimbangaan antara kemampuan berpikir dan kemampuan rasa peserta didik. Hal itulah yang menjadi pertimbangan pemerintah ketika memperkenalkan pendidikan karakter sebagai salah satu poin dari pendidikan nasional. Dengan hadirnya pendidikan karakter, diharapankan pendidikan tidak hanya membentuk kepintaran tetapi juga membentuk moral peserta didik.

Pendidikan karakter merupakan sebuah usaha sadar mendidik peserta didik untuk nilai kebaikan pada diri mereka. (Samawi dan Hariyanto, 2011: 45) mendefinikan pendidikan karakter sebagai sebuah proses untuk menjadikan peserta didik manusia yang seutuhnya yang memiliki esensi kebaikan didimensi hati, pikir, raga, dan rasa. Selain itu pendidikan karakter juga dimaknai sebagai suatu proses pendidkan nilai, pendidikan moral, pendidkan budi pekerti, pendidikan watak yang bertujuan mengembangkan kemampuan peserta didik untuk memberikan keputusan baik dan buruk dan menerapkan nilai-nilai kebaikan tersebut dalam kehidupan sehari-hari. Dengan demikian dapat disimpulkan bahwa pendidikan karakter dapat disebut sebagai usaha sadar yang dilakukan untuk menanamkan nilai karakter kepada peserta yang meliputi pengetahuan, kesadaran atau kemauan, dan tindakan untuk menerapkan nilai-nilai tersebut dalam ruang lingkup terhadap Tuhan Yang Maha Esa ataupun sesama manusia.

Dalam mengupayakan pendidikan karakter dilingkungan sekolah, cara yang terbaik adalah dengan cara mengintegrasikan pendidikan karakter dengan mata pelajaran yang lain. Menurut (Muslich, 2011: 86) pendidikan karakter dapat diintegrasikan pada pembelajaran disetiap mata pelajaran. Materi pembelajaran yang berkaitan dengan norma-norma dan nilai-nilai pada setiap mata pelajaran dikembangkan, diekspilsitkan, dan kaitkan dengan kehidupan sehari-hari. Dengan demikian, pembelajaran karakter tidak hanya pada ranah kognitif tetapi juga menyentuh ranah internalisasi norma dan nilai tersebut pada kehidupan sehari-hari. Sejalan dengan pendapat sebelumnya, (Zuchdi, 2010: 35) juga menjelaskan bahwa salah satu cara dengan pendekatan integrasi norma dan nilai dengan materi pelajaran lain. Nilai dan norma diinternalisasi menjadi tindakan yang diimplemantasikan dalam kehidupan sehari-hari. Sebagai salah satu contoh adalah pembelajaran Bahasa Indonesia yang seharus tidak hanya mengajarkan peserta didik tentang kecakapan berbahasa, tetapi juga harus membentuk peserta didik yang bertanggung jawab, menghormati orang lain, taat beribadah dan sebagainya. 
Dari urian diatas kita dapat menyimpulkan bahwa pengintegrasian pembelajaran Bahasa Indonesia dalam Matematika merupakan suata gagasan yang sangat baik untuk perkembangan peserta didik. Dengan pengintegrasian tersebut guru dapat memberikan stimulasi bagi perkembangan kognitif dan afektif anak secara bersamaan. Dengan pengintergrasiaan tersebut, nilai norma yang ingin diajarkan juga dapat secara langsung diimplementaskan sehingga bisa menjadi kebiasaan yang tertanam didalam diri peseta didik. Selain itu, pendidikan karakter dengan cara pengintegrasian juga akan memudahkan dan meringankan guru dalam mengajar, karena dengan metode pengintegrasian tersebut, guru tidak perlu lagi menambah jam pelajaran untuk mengajarkan dua tujuan pelajaran yang berbeda.

\section{Implementasi Pendidikan karakter di Pengajaran Matematika}

Implementasi bagaimana pegintegrasian pendidikan karakter dengan pengajaran Matematika merupakan informasi yang sangat penting bagi para guru yang akan menerapkan konsep belajar tersebut. Karena tidak bisa dipungkiri bahwa perlu banyak yang harus di pertimbangkan ketika guru akan menerapkan konsep belajar tersebut. Menurut (Zuchdi, 2010: 46-50), ada enam langkah yang dapat ditempuh dalam melaksanakan pendidikan karakter terintegrasi dalam pembelajaran yaitu:

\section{Menentukan Tujuan Pembelajaran}

Sebagaimana proses pembelajaran pada umumnya, seorang guru pasti ingin melaksanakan pembelajaran secara sistematis sesuai dengan urutan kompetensi di dalam standar isi matapelajaran. Maka langkah pertama adalah melihat standar isi mata pelajaran atau silabus yang telah disusunnya. Berdasarkan Standar Kompetensi (SK) dan Kompetensi Dasar (KD), guru menentukan tujuan pembelajaran kognitif, afektif, dan psikomotorik yang akan dicapai melalui materi dan proses pembelajaran.

\section{Menentukan Nilai-nilai Target yang akan dikembangkan}

SK dan KD yang tercantum di dalam standar isi mata pelajaran masih bersifat kognitif, agar hasil belajar sampai pada ranah afektif dan psikomotorik, guru perlu menentukan nilai-nilai yang ditargetkan (nilai target) yang akan diinternalisasi (dihayati) dan diaktualisasi (diamalkan) oleh murid. Nilai target bagi bangsa Indonesia adalah nilai-nilai luhur yang dikristalkan dalam Pancasila. Nilai tersebut jumlahnya tak terhingga, oleh karena itu perlu dipilih yang betul-betul melekat pada 
SK-KD atau materi pembelajaran. Setelah nilai-nilai target ditentukan, selanjutnya dikembangkan indikator capaian hasil belajar yang meliputi pengetahuan tentang nilai-nilai tersebut. Dorongan hati nurani untuk mengamalkannya dalam kehidupan, dan kebiasaan (habit) untuk mengamalkan nilainilai tersebut dalam kehidupan sehari-hari.

\section{Menggunakan Pendekatan Terintegrasi}

Langkah selanjutnya adalah mengembangkan materi pembelajaran dengan pedekatan terintegrasi (terpadu), yaitu perpaduan antara materi pembelajaran dengan nilai-nilai luhur yang diintegrasikan untuk dapat diinternalisasi (dihayati) menjadi acuan perilaku dan terwujud (diamalkan) dalam perbuatan murid sehari-hari sehingga merupakan kebiasaan (habit). Guru dituntut mahir dalam memadukan nilai-nilai target ke dalam materi pembelajaran sehingga sesuai untuk mencapai kompetensi bidang studi tetapi juga sekaligus untuk membentuk karakter murid. Misalnya materi pembelajaran Matematika tidak hanya untuk mengembangkan keterampilan berbahasa tetapi juga untuk membentuk pribadi yang jujur, bertanggungjawab, hormat pada orang lain, taat beribadah dan sebagainya. Oleh karena itu, perlu dipilih tema-tema yang sesuai dengan nilai-nilai tersebut dalam mengembangkan keterampilan menyimak (mendengarkan dengan penuh pemahaman), membaca, berbicara dan menulis serta apresiasi sastra.

\section{Menggunakan Metode Komprehensif}

Selain pendekatan terintegrasi (terpadu), pendidikan karakter memerlukan pendekatan komprehensif. Salah satu ciri dari pendekatan komprehensif adalah penggunaan metode komprehensif. Menurut Kirschenbaum dalam Zuchdi (2010: 46-50) menyebutkan bahwa metode komprehensif merupakan perpaduan antara dua metode tradisional, yaitu inkulkasi (penanaman nilai) dan keteladanan, serta dua metode kentemporer yaitu fasilitasi (memberikan kesempatan kepada murid untuk berlatih membuat keputusan moral), dan pengembangan keterampilan hidup (antara lain: berpikir kritis, berpikir kreatif, berkomunikasi secara efektif, dan mengatasi konflik).

\section{Menentukan Strategi Pembelajaran}

Ada beragam strategi pembelajaran yang dapat menciptakan hasil belajar yang komprehensif (meliputi pemikiran moral, perasaan atau afek mmoral dan perilaku bermoral). Menurut (Zuchdi, 1995: 61-240) menyajikan masing-masing 34 strategi dalam metode inkulkasi (penanaman) nilai, 21 
strategi dalam metode keteladanan nilai, 30 strategi dalam metode fasilitasi nilai, dan 10 strategi dalam metode pengembangan keterampilan (softskills). Dalam memilih strategi pembelajaran untuk pendidikan karakter, perlu diingat bahwa strategi tersebut harus dapat menciptakan situasi belajar yang menyenangkan, aktif, kreatif, bertanggung jawab, dan saling bekerja sama.

\section{Merancang kegiatan yang dapat mengembangkan keterampilan bidang studi dan aktualisasi nilai-nilai target.}

Selama ini terdapat berbagai pendekatan terkait dengan pendidikan karakter, menurut (Zuchdi, 2010: 11) menyatakan bahwa kondisi masa kini sangat berbeda dengan masa lalu. Pendekatanpendidikan karakter yang dahulu cukup efektif, tetapi tidak sesuai lagi untuk membangun generasi sekarang dan yang akan datang. Bagi generasi masa lalu, pendidikan karakter yang bersifat indokrtrinatif sudah cukup memadai untuk membendung terjadinya perilaku memnyimpang dari norma-norma kemasyarakatan, meskipun hal itu tidak mungkin dapat membentuk pribadi-pribadi yang memiliki kemandirian. Sebagai gantinya, diberikan pendekatan pendidikan karakter yang memungkinkan subjek didik mampu mengambil keputusan secara mandiri dalam memilih nilai-nilai yang saling bertentangan seperti yang terjadi pada kehidupan pada saat ini. Strategi tunggal tampaknya sudah tidak cocok lagi, apalagi yang bernuansa indoktrinasi. Pemberian teladan sajajuga kurang efektif diterapkan, karena sulitnya menentukan yang paling tepat untuk dijadikan teladan. Dengan kata lain, diperlukan banyak pendekatan atau yang oleh (Zuchdi, 2010: 12) disebut pendekatan komprehensif. Dari segi metode, pendekatan komperhensif meliputi: inkulkasi nilai; keteladanan (modeling); fasilitasi (facilitation); dan pengembangan ketrampilan (skillbuliding).

\section{SIMPULAN}

Sebagai bahasa yang secara sah diakui sebagai bahasa Negara, Bahasa Indonesia tentu saja memiliki aspek yang sangat kuat sebagai salah produk yang mewakili karakter Bangsa Indonesia. Dengan kata lain, Bahasa Indonesia memiliki moral dan nilai yang merupakan pengejewantahan dari nialai luhur bangsa Indonesia. Ditengah hancur nya karakter bangsa saat ini, diharapkan Bahasa Indonesia bisa memainkan peran nya sebagai salah satu sarana penyadaran kembali akan karakter bangsa yang mulai tergerus oleh rongrongan peradaban modern. Sebagai Bahasa yang diajarkan diseluruh level pendidikan, diharapkan pengajaran Bahasa Indonesia secara tidak langsung juga dapat memberikan angin segar terhadap perbaikan karakter bangsa saat ini. Yang salah satunya dengan 
pengintegrasian pengajran Bahasa dengan Pendidikan karakter disekolah. Pengintegrasian tersebut dilaksanakn dengan menekankan nilai dan moral bangsa yang bisa diajarkan lewat pembelajran Bahasa. Selain itu pengintegrasian tersebut juga harus memperhatikan poin-poin panduan tentnag bagaiaman mengintergrasikan pembelajaran Bahasa Indonesia dengan Pendidikan karakter.

\section{SARAN}

Penulis memberikan saran kepada pembaca agar, diharapkan setelah membaca artikel ini pembaca dapat memahami nilai-nilai karakter pada bahasa Indonesia dan penerapannya pada proses pengembangan karakter matematika di sekolah dasar, yang mana itu berfungsi untuk sarana penyadaran kembali akan karakter bangsa yang mulai tergerus oleh rong-rongan peradaban modern dan juga bahasa Indonesia sebagai pendidikan karakter yang dapat diimplementasikan ke berbagai pelajaran salah satunya matematika.

\section{DAFTAR RUJUKAN}

Camalia, D., Ikhwan, K. W., dan Mujtahidin. 2016. Pendidikan Nilai Moral Melalui Pembelajaran Pantun diSekolah Dasar. PAMATOR Jurnal. 9 (2), hal: 103-108.

Ibrahim. 2008. Prinsip-Prinsip Pembelajaran Bahasa Indonesia. Lentera Pendidikan, 11 (2), hlm: 234-246.

Kenneth S. G. 1992. Pandai Baca Tulis: Untuk Siapa dan Untuk apa, Basa Dalam Pembelajaran. Ed. Makhan L Ticco, Penerjemah Lilian T. Tedjasudhana. Jakarta: Rebia Indah Perkas.

Muslich, M. 2011. Pendidikan Karakter: Menjawab tantangan Krisis Multidimensional. Jakarta: Bumi Aksara.

Pantu, A. dan Luneto, B. 2014. Pendidikan Karakter dan Bahasa. Al-Um, 14 (1), hal: 153-170.

Prasetyo, N. 2011. Membangun Karakter Anak Usia Dini. Kementerian Pendidikan Nasional.

Samawi dan Hariyanto. 2011. Konsepdan Model Pendidikan Karakter. Bandung: Remaja Rosdakarya

Sulistyowati, E. (2013). Pendidikan Karakter dalam Pembelajaran Bahasa Indonesia. Edukasia: Jurnal Penelitian Pendidikan Islam, 8 (2), hlm: 311-330. 